Terbit online pada laman web jurnal : http://teknosi.fti.unand.ac.id/

Jurnal Nasional Teknologi dan Sistem Informasi

ISSN (Print) 2460-3465 | ISSN (Online) 2476-8812 |

Studi Kasus

\title{
Penerapan Metode UCD (User Centered Design) pada E-Commerce Putri Intan Shop Berbasis Web
}

\author{
Intan Sandra Yatana Saputri ${ }^{1}$, Mardhiah Fadhli ${ }^{2}$, Ibnu Surya ${ }^{3}$ \\ ${ }^{1}$ Program Studi Sistem Informasi, Politeknik Caltex Riau, email: intansandray@gmail.com \\ ${ }^{2}$ Program Studi Teknik Komputer,PoliteknikCaltexRiau,email: mardhiah@pcr.ac.id \\ ${ }^{3}$ Program Studi Teknik Informatika, Politeknik Caltex Riau, email: ibnu@pcr.ac.id
}

\section{INFORMASI ARTIKEL}

Sejarah Artikel:

Diterima Redaksi: 05 Juli 2017

Revisi Akhir: 20 Agustus 2017

Diterbitkan Online: 09 September 2017

\section{KATA KUNCI}

User Centered Design

E-Commerce

User Friendly

Usability

KORESPONDENSI

Telepon: +62 85271282277

E-mail: intansandray@gmail.com

\section{A B $\mathbf{S}$ T $\mathbf{R}$ A $\mathbf{C}$ T}

\begin{abstract}
The rapid growth of e-commerce market in Indonesia is indeed already can not doubt. Within a transaction value 130 trillion for e-commerce business in Indonesia. There are e-commerce that still persist and there are also already closed. A report shows that $39 \%$ of buyers test and failed in an attempt to purchase them for navigation on the sites is difficult. To solve the above problems, the required e-commerce development method using User Centered Design (UCD). Objects in this research is Putri Intan Shop. Putri Intan Shop is a shop that caters to physical sales of beauty products. The system that has been built by applying methods of UCD successfully obtained the results of usability testing with an average percentage of $86.8 \%$. Thus, the e-commerce Putri Intan Shop managed to build a user-friendly system with a high level of usability. While the 5 second testing result is $80 \%$ showed that Putri Intan Shop has good impression by user within 5 seconds.
\end{abstract}

\section{PENDAHULUAN}

Pertumbuhan pesat pangsa pasar e-commerce di Indonesia memang sudah tidak bisa diragukan lagi. Dengan jumlah pengguna internet yang mencapai angka 82 juta orang atau sekitar $30 \%$ dari total penduduk di Indonesia, pasar e-commerce menjadi tambang emas bagi sebagian orang yang bisa melihat potensi ke depannya. Pertumbuhan ini didukung dengan data dari Menkominfo yang menyebutkan bahwa nilai transaksi $e$ commerce pada tahun 2013 mencapai angka Rp130 triliun [1].

Salah satu dari permasalahan diatas adalah perusahaan penjual produk kecantikan, Putri Intan Shop. Saat ini perusahaan tersebut sudah memanfaatkan internet sebagai media perkenalan produk mereka, dengan menggunakan salah satu fitur di situs sosial media. Akan tetapi, perusahaan ini masih memanfaatkan sistem penjualan yang konvensional, disaat pembeli langsung bertatap muka dengan penjual, dalam hal ini pelanggan langsung ke perusahaan untuk melakukan pembelian barang. Dengan sistem yang konvensional sering kali perusahaan mengalami berbagai masalah dalam hal penjualan barang untuk pasar yang lebih luas seperti pemasaran barang terhadap pelanggan yang berada di luar kota maupun di dalam kota. Hal ini disebabkan karena penyampaian informasi tentang penjualan perusahaan belum mampu diakses oleh seluruh pelanggan yang ada di Indonesia, padahal Putri Intan Shop telah memiliki beberapa pelanggan yang berasal dari luar daerah. Dengan adanya masalah tersebut Putri Intan Shop sangat merasakan dampaknya seperti tidak terjangkaunya pembeli diluar kota.

Akan tetapi, sistem e-commerce saat ini dibangun hanya fokus dengan tujuan bisnis, fitur yang beragam dan kemampuan pada perangkat lunak dan perangkat keras. Dari semua perancangan, pihak pengembang sistem tidak melibatkan proses yang penting, yaitu keterlibatan pengguna. Bagaimana sebuah sistem dapat dipahami dan digunakan oleh pengguna seharusnya dapat menjadi prioritas utama dalam pengembangan sistem [2] Menurut penelitian yang dilakukan oleh User Interface Engineering, Inc diketahui $60 \%$ waktu terbuang karena orang tidak bisa menemukan informasi yang ingin didapat, dan hal ini berdampak pada penurunan produktifitas dan meningkatkan frustasi [3]. 
Dari permasalahan diatas, dibutuhkan suatu metode User Centered Design (UCD) dalam perancangan e-commerce. Dengan memanfaatkan pendapat pengguna, serta pola dan tingkah laku pengguna. Tujuan penggunaan metode User Centered Design ini adalah untuk mengatasi masalah ketidakmampuan pengguna dalam menggunakan sistem, dan diharapkan pengguna mampu mengetahui fungsi sistem hanya dalam sekali pakai. Metode User Centered Design melibatkan calon pengguna pada tahap awal pengembangan sehingga calon pengguna dapat memberikan masukan mengenai antarmuka sistem e-commerce. Hasil akhir dalam membangun e-commerce ini diharapkan menghasilkan tampilan dan fungsionalitas yang maksimal serta memiliki nilai usability. Metode-metode UCD yang digunakan dalam pengembangan sistem ini adalah kuisioner dan usability testing.

\section{TINJAUAN PUSTAKA}

\subsection{Penelitian Terdahulu}

Penelitian tentang User Centered Design (UCD) ini telah banyak dilakukan berbagai kalangan mahasiswa dan praktisi. Salah satunya adalah penelitian oleh [4]. Pada penelitian tersebut dijelaskan bahwa kesulitan pengguna selama ini adalah membaca dokumen yang ada dalam setiap pengembangan sistem. Masalah ini dapat diselesaikan menggunakan metode UCD dengan menerjemahkan partisipasi pengalaman manusia ke dalam rancangan. Aplikasi yang dibuat adalah kios informasi Rumah Sakit Bersalin XYZ berbasis Visual Basic (VB) pada teknologi Local Area Network (LAN). 80\% pengguna dari aplikasi ini adalah staf rumah sakit dan pasien yang tidak mengerti komputer. Metode yang digunakan untuk spesifikasi sistem adalah wawancara, survei, workshop, dan prototype.

Penelitian yang lain dilakukan oleh [5] dari University of Hongkong. Penelitian ini tidak menghasilkan aplikasi, melainkan sebuah rekomendasi desain website untuk Nine-Year Integrated Curriculum di Taiwan. Penelitian ini dilakukan karena sistem terdahulu tidak digunakan dengan baik karena tidak selesai dan anak-anak tidak mengerti bahasa "profesional" dari sistem tersebut. Pengguna dari sistem ini adalah guru dan murid tingkat sekolah dasar dan menengah.

\subsection{Putri Intan Shop}

Putri Intan Shop merupakan suatu badan usaha milik swasta atau perorangan. Terletak di Jalan Sekolah No. 29 A Rumbai Pekanbaru. Putri Intan Shop sudah berdiri sejak bulan Juli tahun 2007. Badan usaha dibidang kecantikan ini telah menjual berbagai macam produk dengan dinamakan Putri Intan Shop, sedangkan untuk penjualan jasa, Putri Intan Salon \& Spa. Produkproduk yang dijual di toko Putri Intan Shop adalah produk kecantikan seperti vitamin rambut, vitamin wajah serta alat make up lainnya. Bisnis proses pada toko ini masih konvensional, dengan pelanggan datang ke toko fisik untuk melakukan pembelian. Sedangkan gambar produk yang dijualkan, sudah tertera pada fan page di salah satu situs sosial media. Keorganisasian pada toko ini, dimulai dari tingkatan paling atas yaitu pemilik toko dan 4 orang karyawan. Pemilik toko bekerja sebagai kasir toko sedangkan 4 orang karyawan lainnya sebagai pegawai toko.

270 Intan Sandra Yatana Saputri

\subsection{E-Commerce}

E-Commerce ialah suatu proses yang dilakukan konsumen dalam membeli dan menjual berbagai produk secara elektronik dari perusahaan ke perusahaan lain dengan menggunakan komputer sebagai perantara transaksi bisnis yang dilakukan [6].

E-commerce dibedakan menjadi beberapa jenis berdasarkan karakteristiknya yaitu:

1. Business To Business (B2B)

2. Business To Customer (B2C)

3. Customer to Customer (C2C)

4. Customer To Business (C2B)

\subsection{User Centered Design}

User Centered Design (UCD) merupakan paradigma baru dalam pengembangan sistem berbasis web. User centered design (UCD) juga sering disebut sebagai human centered design. Menurut ISO 13407 (1999), human centered design adalah sebuah pendekatan pengembangan sistem interaktif yang secara khusus fokus untuk membuat sebuah sistem berguna. Definisi lainnya menurut [7], user centered design adalah sebuah proses desain interface (antarmuka) yang fokus terhadap tujuan kegunaan, karakteristik pengguna, lingkungan, tugas, dan alur kerja di dalam desainnya. UCD adalah sebuah proses iterative (berulang-ulang), dimana desain dan evaluasi dibangun dari langkah awal hingga implementasi secara terus menerus. Prinsip yang harus diperhatikan dalam UCD adalah:

a. Fokus pada pengguna

b. Perancangan terintegrasi

c. Dari awal berlanjut pada pengujian pengguna

d. Perancangan interaktif

Dalam proses user centered design ini, ada 4 langkah yang dilakukan secara iterasi seperti Gambar 1

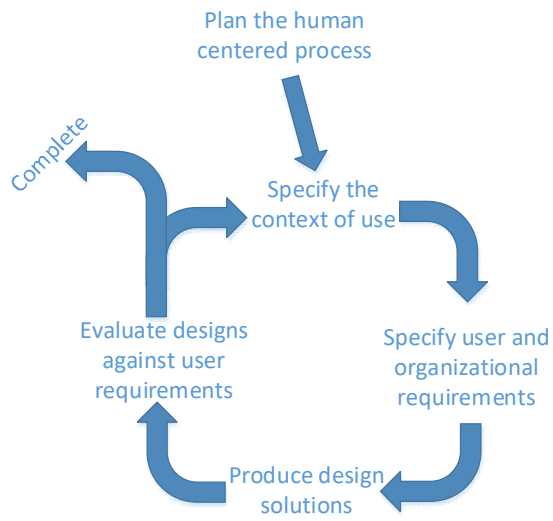

Gambar 1. Tahapan User Centered Design

Sumber: ISO 13409 (1999)

Keterangan gambar:

1. Specify the context of use

Mengidentifikasi orang yang akan menggunakan sistem. Ini akan menjelaskan untuk apa dan dalam kondisi seperti apa, mereka akan menggunakan sistem

2. Specify User and Organizational Requirements Mengidentifikasi kebutuhan pengguna dan kebutuhan organisasi

3. Produce Design Solutions

Membangun desain sebagai solusi dari sistem yang sedang dianalisis

4. Evaluate Design

https://doi.org/10.25077/ TEKNOSI.v3i2.2017.269-278 
Melakukan evaluasi terhadap desain yang dilakukan pada tahap sebelumnya

\subsection{Usability}

Secara informal, usability dapat diartikan sebagai tingkat kemudahan suatu produk untukdigunakan. Berdasarkan ISO usability didefinisikan sebagai “...the effectiveness, efficiency, and satisfaction with which specified users can achieve specified goals in particular environments" (ISO DIS 9241-11). Menurut ahli usability, [8] kriteria - kriteria web usability adalah sebagai berikut:

1. Learnability adalah kriteria yang mengukur tingkat kemudahan suatu situs untuk dipelajari dan digunakan, khususnya bagi pengguna yang baru pertama kali melihat dan menjelajahi situs tersebut.

2. Efficiency adalah kriteria yang mengukur tingkat performansi pengguna ketika menggunakan situs.

3. Memorability adalah kriteria kualitatif yang dapat dilihat melalui kemudahan penggunadalam menggunakan lagi produk (situs) setelah beberapa saat tidak mengunjungi situs.

4. Errors adalah kriteria kuantitatif pada web usability, errors menilai situs melalui banyaknya kesalahan yang dilakukan oleh pengguna ketika melakukan tugas skenario yang diberikan.

5. Satisfaction adalah pengukuran kualitatif yang dirasakan atau juga ditunjukkan oleh pengguna, ketika sistem atau situs yang digunakan menyenangkan dan juga mudah dipakai akan memberikan kenyamanan kepada pengguna atau juga memberikan rasa puas ketika pengguna dapat menyelesaikan tugas yang diberikan dengan baik.

\subsection{Black Box Testing}

Menurut [9] Black Box Testing adalah metode pengujian yang berfokus pada persyaratan fungsional perangkat lunak. Pengujian ini berusaha menemukan kesalahan dalam kategori sebagai berikut:
a. Fungsi yang tidak benar atau hilang
b. Kesalahan interface
c. Kesalahan kinerja

\section{METODOLOGI}

Metodologi dalam melaksanakan penelitian ini adalah dengan melakukan studi untuk melengkapi bahan dari sistem yang akan dibuat, dengan cara mengumpulkan data dari sumber internet, buku, mewawancarai pihak - pihak yang berhubungan dengan pembuatan sistem.

\subsection{Pembelajaran Literatur}

Pembelajaran literatur dilakukan dengan melakukan studi pustaka dengan mempelajari buku-buku dan mengunjungi situs-situs internet yang mendukung penelitian. Pada tahap ini dilakukan pengumpulan bahan-bahan referensi yang digunakan sebagai landasan dalam menyusun penelitian ini. Pembelajaran literatur yang dilakukan mencakup materi mengenai:
a. E-Commerce.
b. Metode User Centered Design.
c. Usability Testing

\section{d. User Experience.}

\subsection{Pengumpulan Data Pengujian}

Metode yang digunakan dalam pengumpulan data adalah kuisioner tertutup. Dengan jumlah sample 30 responden.

\subsection{Perancangan}

Penelitian ini menampilkan perancangan arsitektur sistem, use case diagram, class diagram, EERD (Enhanced Entitiy Relational Diagram).

\subsubsection{Arsitektur Sistem}

Arsitektur sistem adalah suatu pemetaan atau rencana kebutuhankebutuhan sistem yang lebih spesifik secara terstruktur.

Pada gambar 2 terdapat client yang mengakses ke server melalui web browser. Client berupa member dan non member juga admin mengisi data-data yang ada di web browser kemudian mengirimkannya ke server. Pada server, data tersebut akan disimpan di database (MySQL). Di dalam server terdapat web server yang berisi PHP. PHP sebagai bahasa pemrograman yang dipakai. Berikut ini adalah arsitektur sistem secara umum untuk website e-commerce.

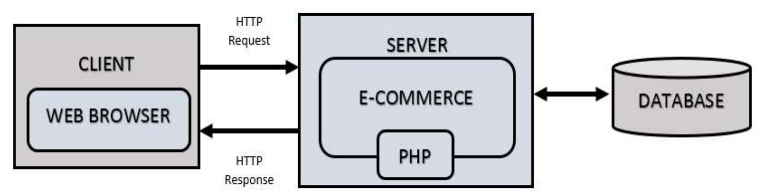

Gambar 2. Arsitektur Sistem E-Commerce

\subsubsection{Use Case Diagram}

Berikut ini adalah usecase diagram pada sistem dapat dilihat pada Gambar 3.

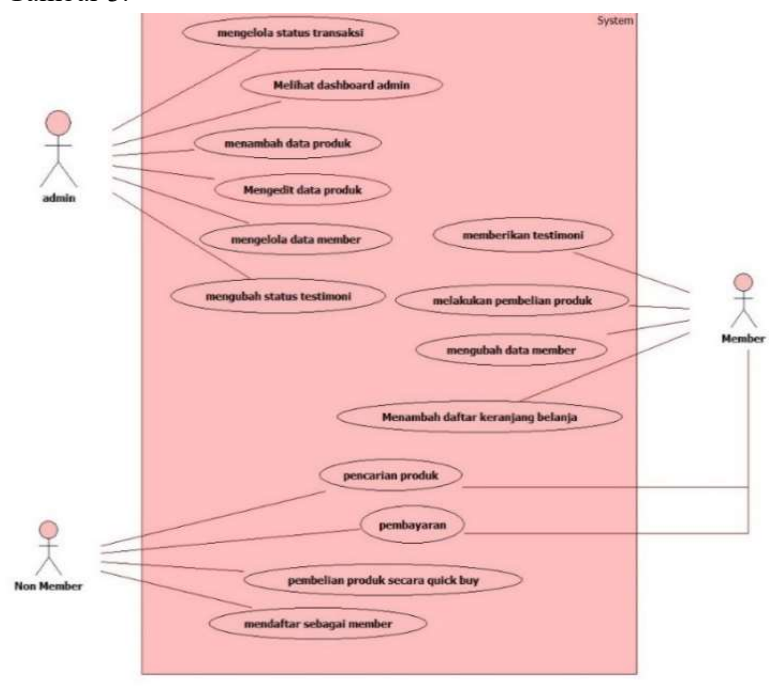

Gambar 3. Use Case Diagram

\subsubsection{Class Diagram}

Class Diagram digunakan untuk hubungan antar kelas, atributatribut dan operasi-operasi yang ada. Perancangan class diagram dari E-Commerce Putri Intan Shop dapat dilihat pada Gambar 4. 


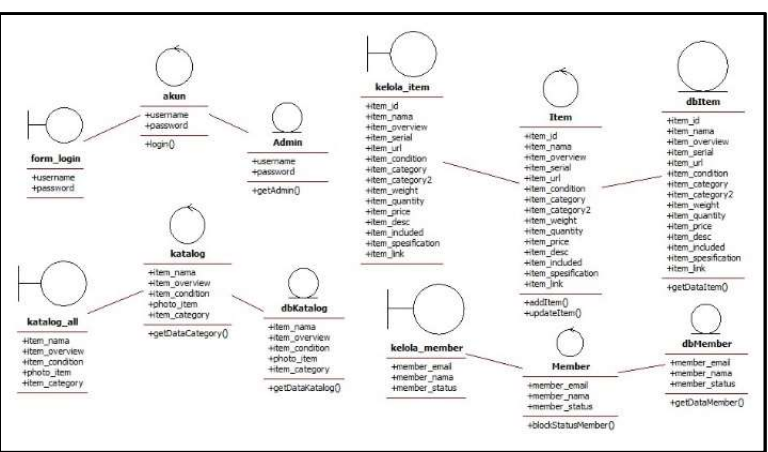

Gambar 4. Class Diagram

\subsubsection{EERD (Enhanced Entity Relational Diagram)}

EERD merupakan model perancangan hubungan antar entitas (tabel) dari sebuah basis data. Perancangan EERD pada sistem ini dapat dilihat pada gambar 5

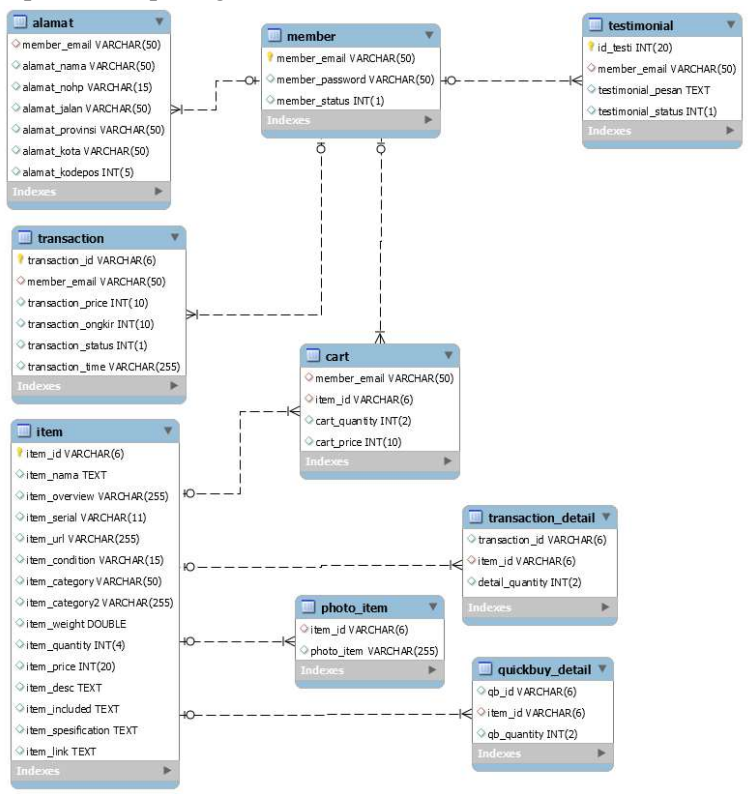

Gambar 5. Enhanced Entity Relational Diagram

\section{HASIL DAN PEMBAHASAN}

\subsection{Analisa User Centered Design}

Pada dasarnya pada tahap ini adalah tahap penggalian informasi atau data untuk mengumpulkan kebutuhan dari pengguna, kemudian setelah informasi atau data terkumpul, dilakukanlah penataan informasi dari data kebutuhan pengguna tersebut, lalu kebutuhan pengguna digambarkan kedalam berbagai bentuk atau teknik, seperti narasi, gambar ataupun diagram. Didalam penelitian ini, menggunakan kuisioner tertutup dengan 33 sample responden untuk menggali kebutuhan pengguna di sistem.

\subsubsection{Memahami konteks pengguna}

Tahap ini merupakan dasar dari setiap metode UCD, yaitu untuk memahami siapa pengguna dari produk yang dimaksudkan dan lingkungan penggunaan mereka. Termasuk juga mengidentifikasi stakeholders, atau siapa saja yang terlibat secara langsung atau tidak langsung dalam pengembangan sistem atau aplikasi. Pada tahap ini dilakukan metode Identify Stakeholders, sebagai berikut:

1. Pemilik Putri Intan Shop sebagai admin pada sistem yang menjadi pembuat kebijakan dan pengawas pengerjaan proyek dari pembuatan sistem sampai pengoperasian sistem

2. Application Designer and Programmer sebagai yang menganalisis kebutuhan sistem, merancang sistem dan membangun sistem

3. Pengguna aplikasi yaitu pelanggan wanita Putri Intan Shop dengan dua jenis pengguna. Sebagai member dan non member

\subsubsection{Kebutuhan pengguna}

Dari beberapa pertanyaan yang telah disebarkan di kuesioner, didapatkanlah beberapa jawaban dari 33 responden untuk mendapatkan daftar kesimpulan fitur visual design Putri Intan Shop, yaitu:

i. Memberikan detail produk yang lengkap, dengan hasil gambar yang nyata, juga menampilkan gambar dengan sudut pandang yang berbeda - beda.

ii. Pada bagian desain katalog produk, lebih mengutamakan desain berbentuk grid atau kotak

iii. Halaman homepage yang sederhana, dengan mengedepankan gambar dari produk yang direkomendasi oleh member dan tidak penuh oleh gambar - gambar yang tidak penting seperti ecommerce yang lain

iv. Tampilan struktur navigasi campuran atau composite, konsisten dan tidak menyulitkan pengguna

v. Adanya fasilitas quick buy bagi non member

vi. Pembuatan menu testimonial bagi member, untuk meningkatkan kepercayaan

\subsubsection{Menghasilkan Solusi Perancangan}

Tahapan ketiga saat pembangunan sistem UCD adalah menghasilkan solusi perancangan. Pada saat menghasilkan solusi perancangan, dilakukan sebanyak tiga kali iterasi pembangunan antarmuka sistem hingga diperoleh solusi perancangan yang benar-benar sesuai dengan kebutuhan pengguna. Berikut merupakan iterasi tiga kali pembangunan.

a. Pembangunan Antarmuka Sistem Tahap 1

Berdasarkan kuesioner yang sudah disebarkan, telah ditemukan hasil pembangunan antarmuka sistem tahap 1. Dapat dilihat pada gambar 6 , antarmuka disajikan kepada pengguna dilengkapi dengan menu pencarian produk dimenu utama. Adanya fitur produk laris juga membantu pengguna dalam melihat produk- produk yang ada di Putri Intan Shop. Pada iterasi 1 ini, dilakukan pengujian usability testing tahap 1. Didapatlah hasil Berdasarkan hasil perhitungan nilai rata-rata likert, diperoleh hasil persentase interval sebesar $68,5 \%$ menunjukkan akurasi mudah dipelajari (learnability), 71,6\% akurasi efisiensi (efficiency), 35,7\% akurasi mudah diingat (memorability), 76,7\% akurasi kesalahan (errors), dan 78,4\% akurasi dari kepuasan (satisfaction). 


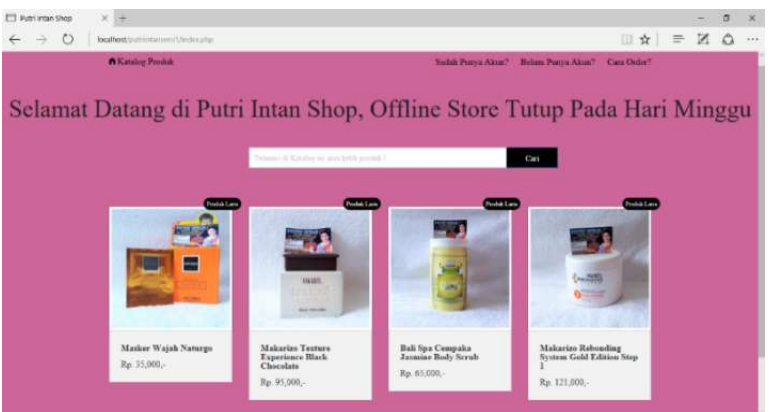

Gambar 6. Iterasi Pertama Antarmuka Sistem

Setelah dilakukan pengujian pada tampilan pembangunan antarmuka sistem tahap 1, diperoleh solusi baru yang sesuai dengan kebutuhan responden, diantaranya:

i. Menambahkan logo Putri Intan Shop pada setiap tampilan halaman antarmuka sistem.

ii. Menghilangkan running text pada halaman awal sistem. Berdasarkan saran yang diberikan oleh responden pada pengisian kuesioner, runningtext dapat mengalihkan fokus pengguna sistem. Pengguna sistem hanya akan memperhatikan informasi yang diberikan oleh running text, sehingga pengguna tidak memiliki ketertarikan dalam melihat informasi lain yang disediakan oleh sistem.

iii. Mengubah warna background pada halaman antarmuka pengguna. Berdasarkan saran yang diberikan oleh responden pada pengisian kuesioner, warna dengan code \#FF6699 tidak sesuai dengan visual design yang dibutuhkan oleh visualisasi pengguna.

b. Pembangunan Antarmuka Sistem Tahap 2

Tahap kedua dalam pembangunan antarmuka sistem disesuaikan berdasarkan solusi baru yang diberikan oleh responden pada tahap pertama yaitu menambahkan logo Puti Intan Shop, menghilangkan fungsi running text, dan merubah warna background dengan code \#FF6699 menjadi \#FFFFFF. Pada iterasi 2 ini, dilakukan pengujian usability testing tahap 2 . Didapatlah hasil Berdasarkan hasil perhitungan nilai rata-rata likert, diperoleh hasil persentase interval sebesar 73,6\% menunjukkan akurasi mudah dipelajari (learnability), 75,6\% akurasi efisiensi (efficiency), 77,9\% akurasi mudah diingat (memorability), 79,4\% akurasi kesalahan (errors), dan 80,1\% akurasi dari kepuasan (satisfaction).

Berikut merupakan tampilan halaman antarmuka sistem yang dibangun pada tahap 2 :

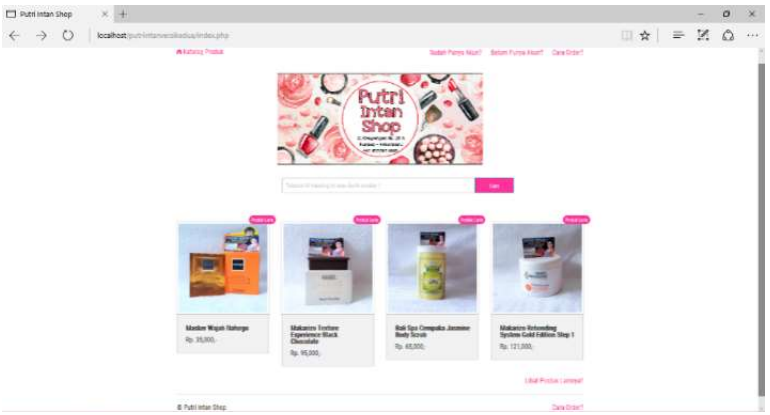

Gambar 7. Iterasi Kedua Antarmuka Sistem

Setelah dilakukan pengujian pada tampilan pembangunan antarmuka sistem tahap 2, diperoleh solusi baru yang sesuai dengan kebutuhan responden, diantaranya:

i. Menambahkan fasilitas dapat memperbesar setiap gambar dari masing-masing produk untuk mendapatkan detail produk dengan jelas. ii. Menambahkan fasilitas riwayat transaksi untuk pengguna, sehingga memudahkan pengguna pada saat ingin melakukan transaksi pada produk yang sama. Hal ini dikarenakan menurut responden, terdapat kendala saat pengguna mengingat kembali jenis produk yang pernah dibeli sebelumnya.

c. Pembangunan Antarmuka Sistem Tahap 3

Tahap ketiga dalam pembangunan antarmuka sistem disesuaikan berdasarkan solusi baru yang diberikan oleh responden pada tahap kedua yaitu menambahkan fasilitas dapa memperbesar setiap gambar dari masing-masing produk untuk mendapatkan detail produk dengan jelas, dan menambahkan fasilitas riwayat transaksi untuk pengguna. Berikut merupakan tampilan halaman antarmuka sistem yang dibangun pada tahap 3 :

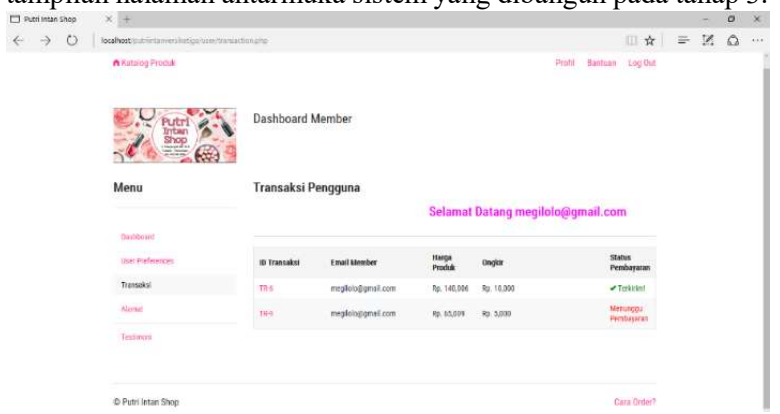

Gambar 8. Iterasi Ketiga Antarmuka Sistem

Setelah dilakukan pengujian pada tampilan pembangunan antarmuka sistem tahap 3, berdasarkan kuesioner yang disebar kepada 33 responden menyatakan sistem yang dibangun telah sesuai dengan kebutuhan pengguna. Tidak terdapat solusi baru yang dibutuhkan oleh pengguna. Maka selanjutnya dilakukan proses instalasi sistem Putri Intan Shop.

Berikut merupakan tampilan halaman sistem yang telah dilakukan instalasi:

\subsubsection{Halaman Utama}

Pada halaman utama, sistem disajikan dengan logo Putri Intan Shop dengan field pencarian dibawah logo. Pengguna telah memiliki pengalaman yang baik ketika sudah tersedianya menu pencarian dihalaman utama. Pengguna tidak perlu mencari dimana field pencarian produk. Tersedianya tag produk laris pada toko fisik juga menambah referensi belanja pengguna. Beberapa menu yang dapat membantu pengguna juga tersedia, seperti menu cara order.

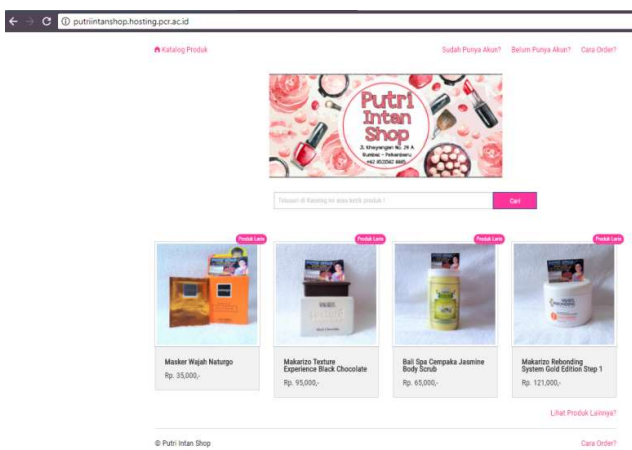

\subsubsection{Halaman Detail Produk}

Pada halaman detail produk, pengguna dapat melihat gambar produk asli dan dilengkapi dengan fitur zoom in \& fitur yang memperlihatkan produk dari segala sisi. Tersedia juga kategori produk serta kandungan yang tersedia juga manfaat dari produk tersebut. Untuk pengguna non member, dapat melakukan transaksi pembelian tanpa mendaftar atau secara quick buy. 


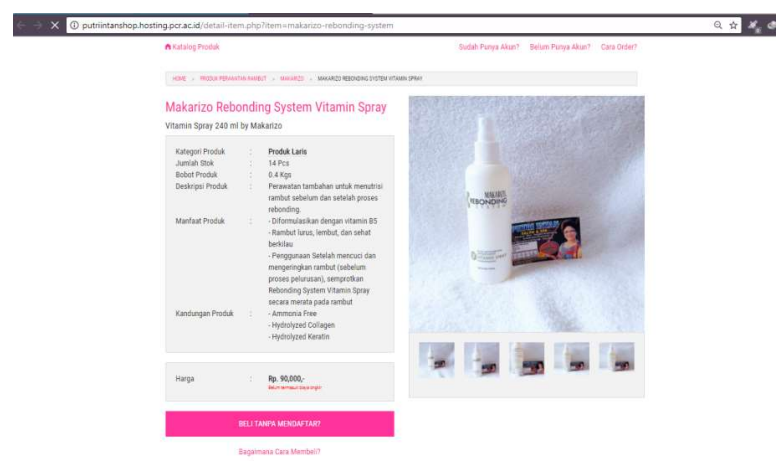

\subsubsection{Halaman Verifikasi Pemesanan}

Pada halaman verifikasi pemesanan, pengguna dapat mengecek kembali pemesanan yang telah order sesuai dengan ID_transaksi pengguna. Dibagian detail pemesanan, sudah tersedia produk yang dibeli beserta harga dan ongkos kirim sesuai alamat yang di input oleh pengguna.

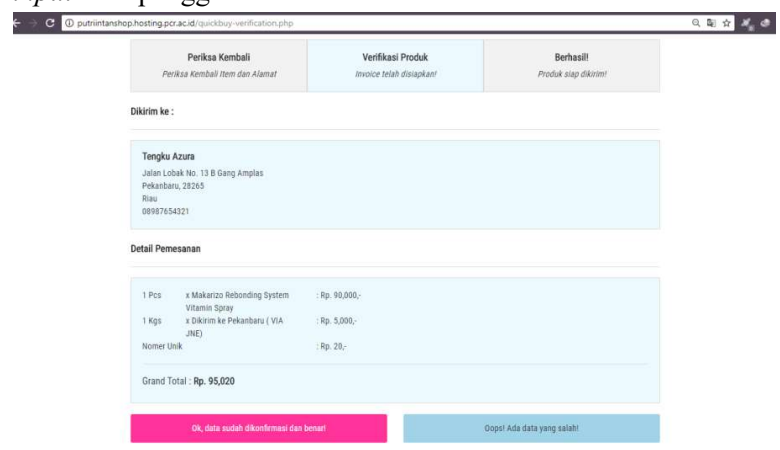

\subsubsection{Halaman Checkout Pemesanan}

Halaman checkout pemesanan yang sederhana juga menjadi salah satu fitur yang diinginkan pengguna. Pengguna hanya perlu total belanja dan juga kemana pengguna akan melakukan pembayaran. Dihalaman ini, pengguna juga disediakan menu tracking order juga menu konfirmasi pembayaran yang terdapat pada menu profil member

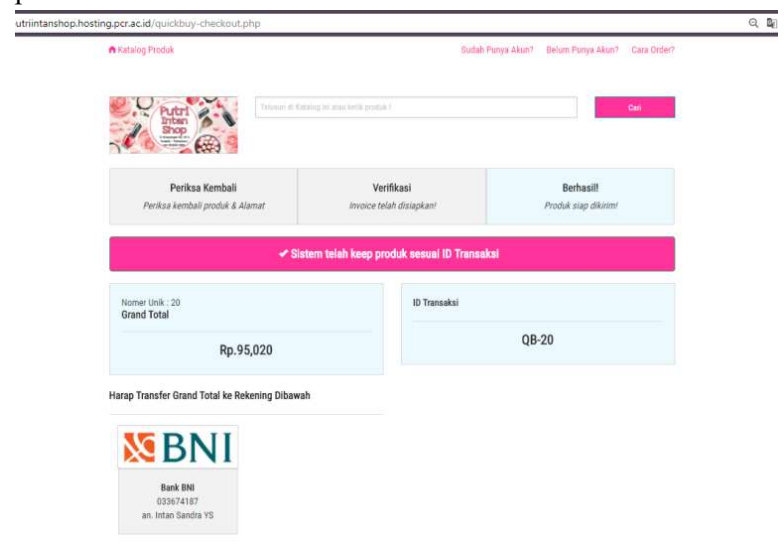

\subsubsection{Halaman Katalog Produk}

Halaman katalog produk memberikan beberapa produk baik itu produk baru ataupun produk laris. Adanya informasi harga dan juga gambar produk menjadikan pengguna dapat dengan mudah melihat isi katalog produk Putri Intan Shop.

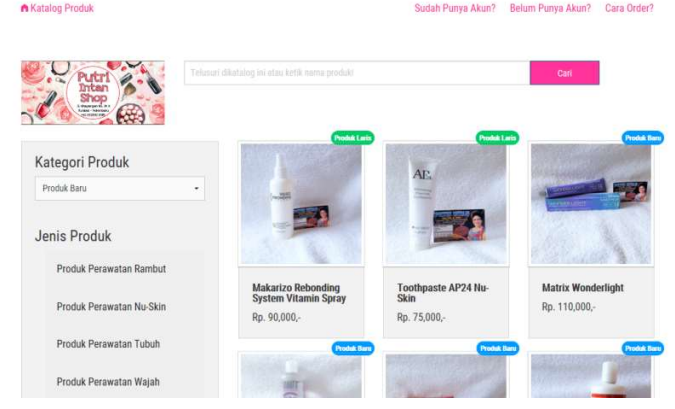

\subsubsection{Evaluasi Desain Terhadap Kebutuhan}

Berikut merupakan alur blok diagram dari tahapan evaluasi desain terhadap kebutuhan pengguna pada sistem Putri Intan Shop yang telah dibangun:

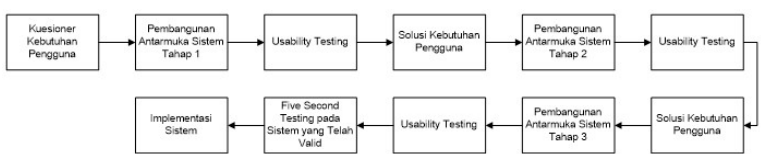

Gambar 9. Blok Diagram Sistem

Tahap pertama adalah melakukan penyebaran kuesioner kepada 33 responden untuk mengetahui kebutuhan pengguna. Kuesioner yang disebar sebelum pembangunan sistem ini terdiri dari 6 jumlah pernyataan. Berdasarkan pernyataan-pernyataan tersebut, diperoleh 6 kesimpulan fiturfitur dan visual design yang dibutuhkan oleh pengguna sistem.

Tahapan selanjutnya adalah pembangunan antarmuka sistem tahap 1. Pada tahapan ini, dibangunlah sistem Putri Intan Shop berdasarkan kesimpulan fitur-fitur dan visual design yang diperoleh dari kuesioner yang telah disebar sebelumnya. Setelah sistem dibangun, dilakukan tahapan selanjutnya yaitu tahapan usability testing yang melakukan pengujian terhadap sistem yang telah dibangun pada tahap pertama.

Setelah dilakukan pengujian pada sistem yang telah dibangun pada tahap 1 , diperoleh 3 solusi baru kebutuhan pengguna. Solusi tersebut merupakan hasil dari penyebaran kuesioner usability testing yang disebar pada pembangunan sistem tahap 1. Diperoleh nilai rata-rata usability testing pada iterasi 1 sebesar $66,2 \%$. Tahapan selanjutnya adalah pembangunan antarmuka sistem tahap 2 yang sudah dilengkapi dengan solusi baru kebutuhan pengguna.

Setelah pembangunan sistem tahap 2, dilakukan pengulangan pengujian usability testing tahap 2 dan diperoleh 2 solusi baru kebutuhan pengguna. Untuk iterasi 2, diperoleh rata-rata usability testing sebesar $77,3 \%$. Sama seperti proses sebelumnya, dilakukan pembangunan sistem tahap 3 yang telah dilengkapi dengan solusi baru kebutuhan pengguna berdasarkan usability testing apda tahap 2 . Pada pembangunan sistem tahap 3, responden menyatakan kepuasannya terhadap sistem yang telah dibangun sehingga tidak memicu lahirnya solusi baru kebutuhan pengguna seperti proses sebelumnya. Pada tahapan ini, dilakukan evaluasi perhitungan berdasarkan bobot dari masing-masing alternatif jawaban yang disediakan pada masing-masing pernyataan sehingga diperoleh $86,8 \%$ sebagai nilai dari evaluasi usability testing.

Evaluasi terakhir yang dilakukan adalah pengujian 5 second testing yang digunakan untuk mengetahui kesan pertama pengguna dalam menggunakan sistem dalam kurun waktu 5 detik. 


\subsection{Pengujian}

\subsubsection{Black Box Testing}

Pada pengujian ini, berfokus pada persyaratan fungsional sistem berdasarkan fungsi dan menu yang tersedia. Pengujian ini dilaksanakan bersamaan dengan pengambilan data untuk usability testing. Adapun simpulan dari halaman yang diuji, dapat dilihat pada tabel 1

Tabel 1. Pengujian Black Box

\begin{tabular}{|c|c|c|}
\hline $\begin{array}{c}\text { Fungsi Skenario } \\
\text { Uji }\end{array}$ & $\begin{array}{c}\text { Hasil yang } \\
\text { Diharapkan }\end{array}$ & Kesimpulan \\
\hline $\begin{array}{l}\text { Melakukan login } \\
\text { admin }\end{array}$ & $\begin{array}{l}\text { Jika username yang } \\
\text { diinputkan sesuai } \\
\text { dengan yang ada di } \\
\text { database, maka akan } \\
\text { diarahkan ke halaman } \\
\text { index admin. Jika tidak, } \\
\text { sistem akan } \\
\text { menampilkan "Sepertinya } \\
\text { peringatan "Separdak } \\
\text { username anda tidak } \\
\text { terdaftar di sistem ini. } \\
\text { Halaman akan } \\
\text { diteruskan ke halaman } \\
\text { mendaftar dalam waktu } \\
5 \text { detik" }\end{array}$ & BERHASIL \\
\hline $\begin{array}{l}\text { Melakukan login } \\
\text { member }\end{array}$ & $\begin{array}{l}\text { Jika email member yang } \\
\text { diinputkan sesuai } \\
\text { dengan yang ada di } \\
\text { database, maka akan } \\
\text { diarahkan ke halaman } \\
\text { index member. Jika } \\
\text { username tidak ada di } \\
\text { database, sistem akan } \\
\text { menampilkan pesan } \\
\text { "Sepertinya email anda } \\
\text { belum pernah } \\
\text { didaftarkan, silahkan } \\
\text { mendaftar terlebih } \\
\text { dahulu. Halaman ini } \\
\text { akan diteruskan ke } \\
\text { halaman mendaftar } \\
\text { dalam waktu } 5 \text { detik." } \\
\text { Jika username ada di } \\
\text { database, tetapi } \\
\text { password salah. Sistem } \\
\text { akan menampilkan } \\
\text { pesan "Mohon periksa } \\
\text { kembali password anda. } \\
\text { Halaman ini akan } \\
\text { diteruskan ke halaman } \\
\text { login dalam waktu } 5 \\
\text { detik." }\end{array}$ & BERHASIL \\
\hline $\begin{array}{l}\text { Melakukan } \\
\text { pendaftaran } \\
\text { member }\end{array}$ & $\begin{array}{l}\text { Pengguna melakukan } \\
\text { pendaftaran dengan } \\
\text { input email dan } \\
\text { password. Setelah } \\
\text { mengklik tombol daftar } \\
\text { menjadi member, sistem } \\
\text { akan menampilkan } \\
\text { pesan "Terimakasih } \\
\text { sudah mendaftar, harap } \\
\text { mengisi data diri agar } \\
\text { mempermudah } \\
\text { pembayaran. Halaman } \\
\text { ini akan diteruskan ke }\end{array}$ & BERHASIL \\
\hline
\end{tabular}

\begin{tabular}{|c|c|c|}
\hline & $\begin{array}{l}\text { halaman login dalam } \\
\text { waktu } 5 \text { detik." }\end{array}$ & \\
\hline $\begin{array}{l}\text { Melakukan } \\
\text { pengisian data } \\
\text { diri member }\end{array}$ & $\begin{array}{l}\text { Ketika member login } \\
\text { dan pertama kali } \\
\text { mengakses halaman } \\
\text { "profil". Member akan } \\
\text { diarahkan ke halaman } \\
\text { pengisian data diri. } \\
\text { Setelah member berhasil } \\
\text { melakukan pengisian } \\
\text { data diri, member } \\
\text { diarahkan ke halaman } \\
\text { dashboard member. }\end{array}$ & BERHASIL \\
\hline $\begin{array}{l}\text { Melakukan } \\
\text { pembayaran }\end{array}$ & $\begin{array}{l}\text { Pembayaran akan valid } \\
\text { ketika admin menerima } \\
\text { uang sesuai dengan id } \\
\text { transaksi yang ada } \\
\text { dimenu transaksi. lalu } \\
\text { member akan konfirmasi } \\
\text { pembayaran pada menu } \\
\text { profil }\end{array}$ & BERHASIL \\
\hline $\begin{array}{l}\text { Memberikan } \\
\text { testimonial }\end{array}$ & $\begin{array}{l}\text { Testimoni hanya dapat } \\
\text { ditambah jika member } \\
\text { sudah melakukan } \\
\text { pembelian produk }\end{array}$ & BERHASIL \\
\hline $\begin{array}{l}\text { Pencarian } \\
\text { produk }\end{array}$ & $\begin{array}{l}\text { Menampilan produk } \\
\text { yang dicari sesuai yang } \\
\text { ada pada database, jika } \\
\text { tidak ada produk yang } \\
\text { dicari ditampilkan pesan } \\
\text { tidak ada produk yang } \\
\text { ditemukan }\end{array}$ & BERHASIL \\
\hline $\begin{array}{l}\text { Pembelian } \\
\text { quickbuy }\end{array}$ & $\begin{array}{lr}\text { Pengguna } & \text { dapat } \\
\text { langsung } & \text { membeli } \\
\text { produk yang diinginkan, } \\
\text { dengan mengklik tombol } \\
\text { beli tanpa } & \text { mendaftar. } \\
\text { Pengguna } & \text { akan } \\
\text { diarahkan } & \text { kehalaman } \\
\text { pengisian } & \text { alamat } \\
\text { penerima. } & \end{array}$ & BERHASIL \\
\hline $\begin{array}{l}\text { Menambah isi } \\
\text { keranjang } \\
\text { belanja }\end{array}$ & $\begin{array}{l}\text { Menampilkan isi } \\
\text { keranjang belanja, } \\
\text { sesuai produk yang klik } \\
\text { tambahkan ke keranjang } \\
\text { belanja }\end{array}$ & BERHASIL \\
\hline
\end{tabular}

\subsubsection{Second Testing}

Metode yang digunakan untuk pengujian adalah 5 Second Testing yang menemukan kesan pertama sebuah desain dalam waktu 5 detik sehingga dapat memastikan apakah pesan dari desain tersebut dapat diterima oleh pengguna dengan efektif atau tidak. Objek yang diteliti adalah 33 anonymous, sehingga pengguna akan melihat tampilan awal website lalu mengumpulkan informasi yang mampu disimpan dalam waktu 5 detik. Setelah itu anonymous akan diberi 3 pertanyaan yang menyangkut tentang pengujian 5 second testing (Beck, 2003).

Dari pertanyaan pertama, sebanyak 25 dari 33 anonymous atau $75 \%$ dapat menjawab pertanyaan dengan berbagai macam jawaban tetapi masih dalam lingkup produk kecantikan dan wanita. Pada pertanyaan kedua, 28 dari 33 anonymous atau $84 \%$ memberikan berbagai jawaban yang sesuai dengan yang ada di tampilan halaman sistem seperti; logo Putri Intan Shop, background berwarna putih, field pencarian produk dan gambar produk kecantikan. Pada pertanyaan terakhir, 27 dari 33 anonymous atau $81 \%$ menjawab logo Putri Intan Shop dan produk kecantikan yang ada dihalaman utama sistem. 


\subsubsection{Usability Testing}

Berikut merupakan pengujian usability testing yang dilakukan dengan menggunakan metode perhitungan Skala Likert:

Persentase Interval $=\frac{100}{5}=20$ menunjukkan interval

Tabel 2. Tabel Persentase Interval

\begin{tabular}{cc}
\hline $\begin{array}{c}\text { Persentase } \\
\text { Interval }\end{array}$ & Kriteria \\
\hline $\mathbf{0 \%}-\mathbf{1 9 , 9 9 \%}$ & Sangat Tidak Setuju \\
\hline $\mathbf{2 0 \%}-\mathbf{3 9 , 9 9 \%}$ & Tidak Setuju \\
\hline $\mathbf{4 0 \%}-\mathbf{5 9 , 9 9 \%}$ & Netral \\
\hline $\mathbf{6 0 \% - 7 9 , 9 9 \%}$ & Setuju \\
\hline $\mathbf{8 0 \% - 1 0 0 \%}$ & Sangat Setuju \\
\hline
\end{tabular}

Tabel 3. Tabel Perhitungan Likert

\begin{tabular}{lllllll}
\hline Pernyataan & STS & TS & N & S & SS & $\begin{array}{c}\text { Rata- } \\
\text { Rata }\end{array}$
\end{tabular}

Likert

\begin{tabular}{|c|c|c|c|c|c|c|}
\hline P1 & 0 & 0 & 12 & 9 & 12 & $84,5 \%$ \\
\hline P2 & 0 & 0 & 10 & 17 & 6 & \\
\hline P3 & 0 & 0 & 10 & 17 & 6 & \\
\hline P4 & 0 & 0 & 15 & 12 & 6 & \\
\hline P5 & 0 & 0 & 10 & 16 & 7 & $88,9 \%$ \\
\hline P6 & 0 & 0 & 11 & 15 & 7 & \\
\hline P7 & 0 & 0 & 14 & 12 & 7 & \\
\hline P8 & 0 & 0 & 13 & 17 & 5 & $87,8 \%$ \\
\hline P9 & 0 & 0 & 13 & 14 & 6 & \\
\hline P10 & 0 & 0 & 12 & 11 & 10 & $86,7 \%$ \\
\hline P11 & 0 & 0 & 13 & 16 & 4 & \\
\hline P12 & 0 & 0 & 12 & 12 & 9 & $86 \%$ \\
\hline P13 & 0 & 0 & 10 & 15 & 8 & \\
\hline P14 & 0 & 0 & 9 & 10 & 14 & \\
\hline P15 & 0 & 2 & 3 & 11 & 17 & \\
\hline
\end{tabular}

Berdasarkan hasil perhitungan nilai rata-rata likert, diperoleh hasil persentase interval sebesar $84,5 \%$ menunjukkan akurasi mudah dipelajari (learnability), 88,9\% akurasi efisiensi (efficiency), 87,8\% akurasi mudah diingat (memorability), 86,7\% akurasi kesalahan (errors), dan $86 \%$ akurasi dari kepuasan (satisfaction).

\subsection{Analisis Pengujian}

Untuk menilai tingkat keberhasilan dari tugas akhir yang telah dibuat, maka dilakukan analisis berupa pengujian black box, usability testing dan 5 second testing.

\subsubsection{Analisis Black Box Testing}

Berdasarkan hasil pengujian black box yang telah dilakukan, didapatkan hasil bahwa seluruh kebutuhan fungsional dari sistem yang dibangun telah terpenuhi dan berjalan dengan baik.

\subsubsection{Analisis Pengujian Usability Testing}

Berdasarkan hasil pengujian melalui nilai kebergunaan atau usability. Pada penelitian ini, usability untuk tiap-tiap iterasi menghasilkan nilai yang berbeda. Semakin tinggi tahap iterasi yang dilakukan, maka atas saran yang didapat dari pengguna. Semakin tinggi pula nilai usability yang didapatkan. Berikut perbandingan nilai usability yang dirangkum pada tabel berikut:
Tabel 4. Perbandingan nilai Usability tiap Iterasi

\begin{tabular}{lllllll}
\hline $\begin{array}{l}\text { Ite } \\
\text { ra } \\
\text { si }\end{array}$ & $\begin{array}{l}\text { Learna } \\
\text { bility }\end{array}$ & $\begin{array}{l}\text { Effici } \\
\text { ency }\end{array}$ & $\begin{array}{l}\text { Memor } \\
\text { ability }\end{array}$ & $\begin{array}{l}\text { Err } \\
\text { ors }\end{array}$ & $\begin{array}{l}\text { Satisf } \\
\text { action }\end{array}$ & Average \\
\hline $\mathbf{1}$ & $68,5 \%$ & $71,6 \%$ & $35,7 \%$ & $\begin{array}{l}76,7 \\
\%\end{array}$ & $\begin{array}{l}78,4 \\
\%\end{array}$ & $\mathbf{6 6 , 2 \%}$ \\
\hline $\mathbf{2}$ & $73,6 \%$ & $75,6 \%$ & $77,9 \%$ & $\begin{array}{l}79,4 \\
\%\end{array}$ & $\begin{array}{l}80,1 \\
\%\end{array}$ & $\mathbf{7 7 , 3 \%}$ \\
& & & & & & \\
& & & & & & \\
\hline $\mathbf{3}$ & $84,5 \%$ & $88,9 \%$ & $87,8 \%$ & $\begin{array}{l}86,7 \\
\%\end{array}$ & $86 \%$ & $\mathbf{8 6 , 8 \%}$ \\
& & & & & & \\
& & & & & & \\
& & & & & &
\end{tabular}

Pada faktor learnability, didapat masalah pada kesulitan pengguna dalam mempelajari halaman utama sistem. Pengguna lebih fokus kepada fitur marquee text yang ada pada halaman utama. Sehingga untuk melihat fitur lain, pengguna sudah merasa tidak ingin lagi melihat halaman utama lebih jauh. Setelah dilakukan iterasi sampai tiga kali, maka pengguna sudah dapat mempelajari halaman utama sistem karna tulisan yang digunakan pada halaman utama dapat dibaca dan fokus utama pengguna dapat langsung melihat ke gambar produk. Untuk faktor memorability, pada iterasi pertama pengguna tidak mudah ingat fitur apa saja yang ada pada halaman sistem. Visual design bagaimana pada halaman sistem. Maka dengan menambahkan beberapa fitur dari saran pengguna seperti menambahkan logo, maka nilai memorability Putri Intan Shop pada iterasi tahap akhir mencapai $86,8 \%$

Berdasarkan System Usability Scale (SUS), range nilai kebergunaan dapat dilihat pada gambar 4.10. Putri Intan Shop ada pada range excellent yaitu sebesar $86,8 \%$. Maka dari itu, ecommerce Putri Intan Shop berhasil membangun sistem yang user-friendly dengan tingkat usability yang tinggi.

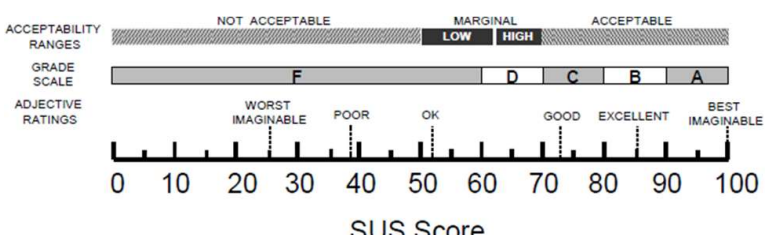

Gambar 10. System Usability Scale (SUS), Sumber : (Bangor, 2008)[11]

Putri Intan Shop ada pada range excellent yaitu sebesar $86,8 \%$. Maka dari itu, e-commerce Putri Intan Shop berhasil membangun sistem yang user-friendly dengan tingkat usability yang tinggi.

\subsubsection{Analisis Pengujian 5 Second Testing}

Untuk mendapatkan kepercayaan dari pengguna, yang pertama dilakukan adalah $e$-commerce harus memberikan kesan pertama yang baik. Salah satu caranya yaitu e-commerce harus memiliki visual design yang baik. Pengguna dapat mengingat beberapa tampilan dan fitur pada halaman utama sistem. Sehingga sistem tersebut memiliki first impression yang baik bagi pengguna.

Setelah dilakukan pengujian 5 Second Testing, 80\% pengguna menunjukan halaman sistem Putri Intan Shop berhasil memberikan kesan dan pesan yang disampaikan diterima pengguna dalam waktu 5 detik. 


\section{KESIMPULAN DAN SARAN}

\subsection{Kesimpulan}

Setelah dilakukan implementasi berdasarkan perancangan, didapatkan kesimpulan sebagai berikut:

1. Berdasarkan Usability Testing dengan System Usability Scale, Putri Intan Shop ada pada range excellent yaitu sebesar 86,8\%. Maka dari itu, e-commerce Putri Intan Shop berhasil membangun sistem yang user-friendly dengan tingkat usability yang tinggi.

2. Berdasarkan 5 second testing. Rata-rata persentase sebesar $80 \%$ menunjukan halaman sistem Putri Intan Shop berhasil memberikan kesan dan diterima pengguna dalam waktu 5 detik.

\subsection{Saran}

Adapun saran yang dapat dijadikan pertimbangan untuk pengembangan penelitian selanjutnya adalah Pembangunan $e$ commerce yang berbasis mobile atau berbentuk sebuah aplikasi.

\section{DAFTAR PUSTAKA}

[1] Kementerian Komunikasi dan Informasi Indonesia. (8 Mei 2017). Kemkominfo: Pengguna Internet Indonesia Nomor Enam Dunia. Diambil 7 Juni 2017 dari https://kominfo.go.id/content/detail/4286/penggunainternet-indonesia-nomor-enamdunia/0/sorotan_media

[2] UX Mastery. (t.t). UX Techniques. Retrieved May 31, 2016 from http://uxmastery.com/resources/techniques

[3] Usability.gov (2004). Usability Testing. Retrieved May 31, 2016 from www.usability.gov/tools /usabilitytesting.html

[4] Widhiarso, Wijang. (2007). Metode UCD (User Centered Design) Untuk Rancangan Kios Informasi Studi Kasus : Rumah Sakit Bersalin XYZ. Jurnal Informatika Vol III No III.

[5] Liang, C., Chou, W., Hsu, Y. (2009). A User-Centered Design Approach to Develop a Web-Based Instructional Resources System for Homeland Education. An International Journal.

[6] Laudon, K. C., Travis, J. (2002). E-Commerce: Bussiness. Technology. Society, United States of America: Prentice Hall.

[7] Henry, S. L. (2004). Notes on User-Centered Design Process (UCD). Retrieved January 3, 2017 from http://www.w3.org/WAI/EO/2003/ucd.

[8] Nielsen, Jacob (1994). Usability Engineering Interactive Technologies. Morgan Kauffman.

[9] Pressman, Roger. S (2010). Software Engineering: A Practitioner's Approach, Seventh (7th) Edition. New York: McGraw-Hill.

[10] Putra, R. S. (2015). Pengembangan Personalisasi Website E-Commerce Berbasis Metode User Centered Design. Jurnal Informatika Vol VIII No I.

[11] Bangor, A., Kortum, P., \& Miller, J.A. (2008). The System Usability Scale (SUS): An Empirical Evaluation. An International Journal of HumanComputer Interaction.

\section{BIODATA PENULIS}

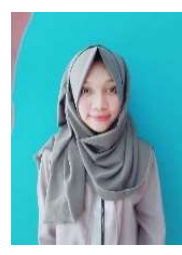

Penulis Pertama

Intan Sandra Yatana Saputri, beralamat

Di Jalan Sekolah Rumbai Pekanbaru.

\section{LAMPIRAN}

\section{LAMPIRAN A}

Kuesioner Usability Testing (Nilai Kebergunaan)

Pengajuan beberapa pertanyaan setelah website atau aplikasi $e$ commerce dibuat. Dipaparkan beberapa pertanyaan mengenai nilai kebergunaan suatu website atau aplikasi. Seperti Tabel C.1

\section{USABILITY TESTING}

Nama Responden :

Jenis Kelamin

Usia

Mohon berikan tanda $(\sqrt{ })$ pada kolom alternatif jawaban yang Ibu anggap paling tepat mencerminkan persepsi Ibu. Terdapat lima (5) alternatif jawaban yang dapat digunakan untuk masingmasing pernyataan, yaitu:

$1=$ Sangat Tidak Setuju

$2=$ Tidak Setuju .

$3=$ Netral.

$4=$ Setuju.

$5=$ Sangat Setuju.

Jika Ibu memilih alternatif jawaban 1 (Sangat Tidak Setuju) dan 2 (Tidak Setuju) mohon isi kolom saran. Agar pembangunan sistem dapat diperbaiki.

1. Usability Testing

Pernyataan-pernyataan dibawah ini berkaitan dengan persepsi Bapak/Ibu terhadap sistem informasi software aplikasi.

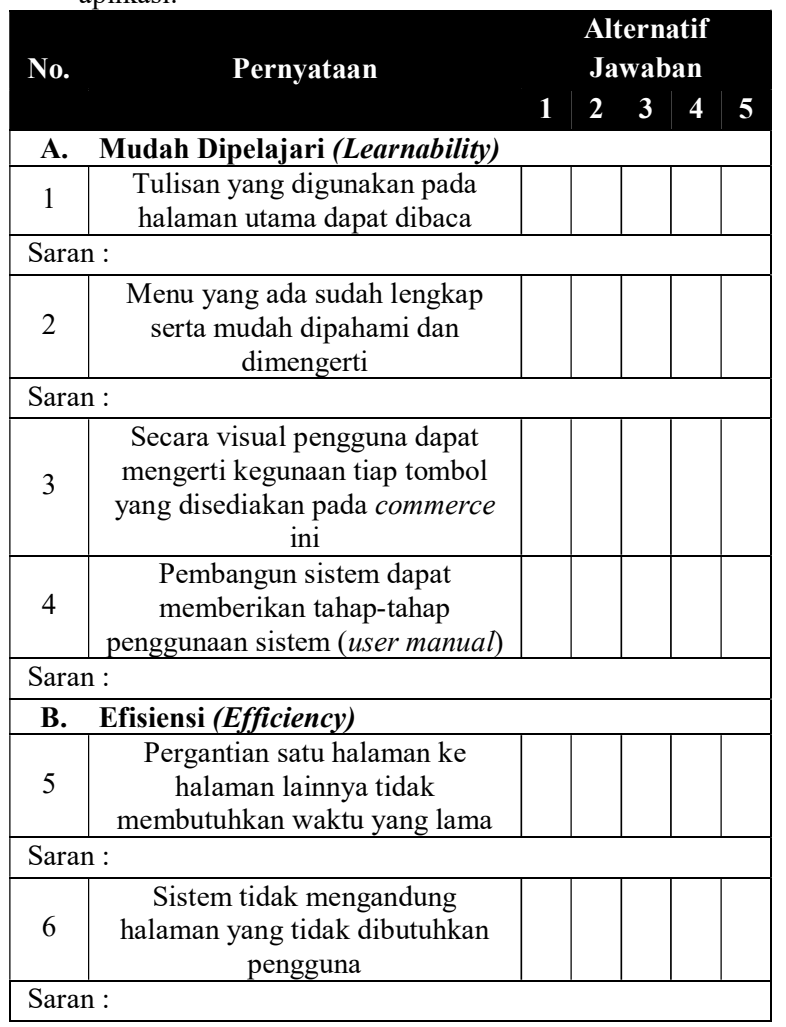




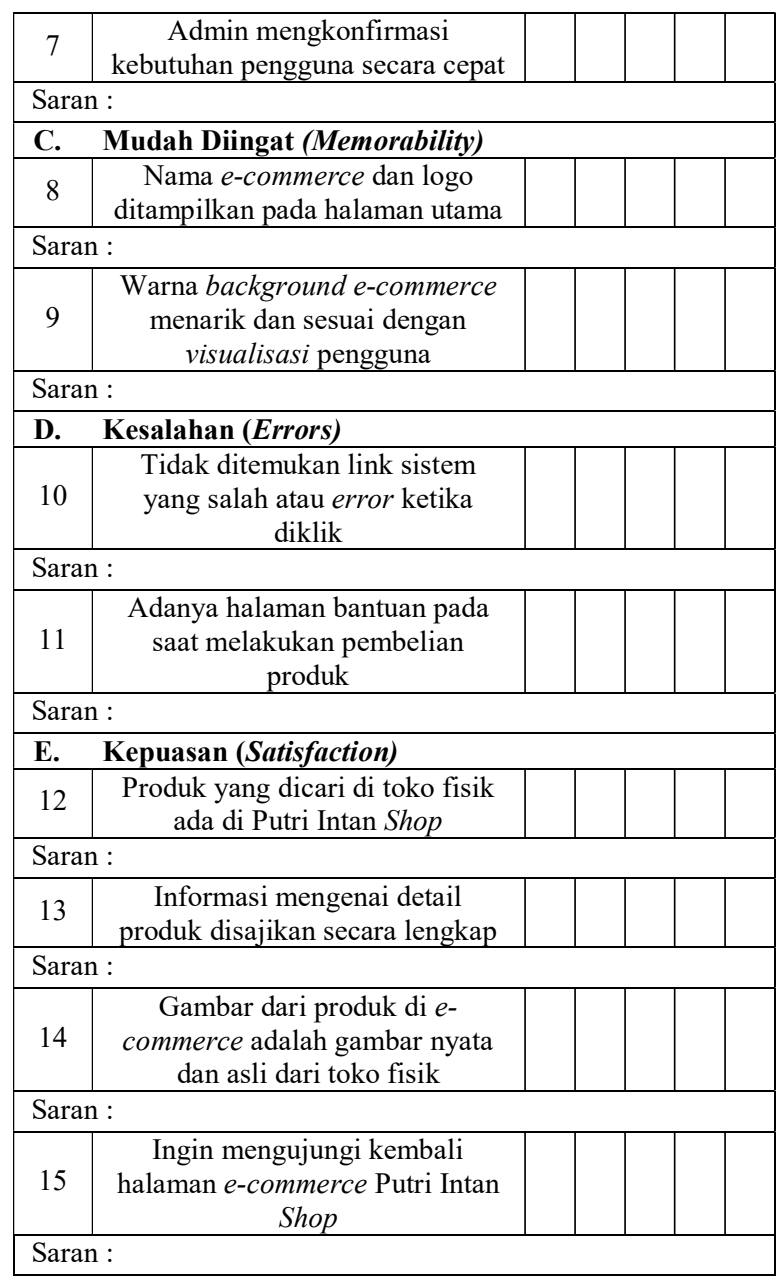

\section{LAMPIRAN B}

5 Second Testing dan Kuesioner

Berikut adalah sampel data pengujian 5 second testing mengenai e-commerce Putri Intan Shop serta pengujian kuesioner yang langsung dilakukan kepada objek. Untuk 5 Second Testing ini dilakukan terhadap anonymous objek

Nama

\section{SECOND TESTING}

Usia :

Jawablah beberapa pertanyaan mengenai sistem yang anda lihat tadi berdasarkan kesan 5 detik pertama.

Sumber: (Kent Beck, 2008)

1. Apa yang dijual atau ditawarkan pada sistem ini?

2. Apa yang paling disukai pada tampilan halaman sistem ini?

3. Apa yang menjadi fokus utama ketika melihat sistem ini pertama kali? 